\title{
Lack of association between cytomegalovirus infection of heart and rejection-like inflammation
}

\author{
P G I STOVIN, T G WREGHITT, * T A H ENGLISH, J WALLWORK \\ From the Papworth Hospital, Papworth Everard, Cambridge, and the *Clinical Microbiology and Public Health \\ Laboratory, Addenbrooke's Hospital, Cambridge
}

SUMMARY Serial myocardial biopsy specimens, taken up to the time of serological evidence of primary cytomegalovirus (CMV) infection in 22 heart transplant patients, were examined and compared with those taken over similar times after transplantation in 21 patients who did not develop CMV infection. None of these 43 patients had serological evidence of CMV infection before their heart transplantation. There was no evidence of an increased cellular infiltrate in the myocardium at the time of the active CMV infection, even though the donor heart is the likeliest source of infection, nor was there any change in myocyte, interstitial cell, or vascular endothelial cell nuclei to identify active CMV infection.

Cytomegalovirus (CMV) infection often occurs after heart transplantation and primary infection is usually associated with high morbidity, especially when the infection is acquired from the donor organ. ${ }^{1}$ Histopathological descriptions of cardiac CMV infection are rare. ${ }^{2-4}$ Even in lethal, severe primary CMV infection it has been shown by nucleic acid hybridisation that myocardial cells carrying viral DNA appear quite normal on conventional histological examination and may therefore be able to act as a latent source of infection. ${ }^{3}$

Distinguishing between CMV infection and rejection in transplanted kidneys may be difficult. Richardson et al described a glomerular lesion in CMV infection in the transplanted kidney which they regarded as distinct from rejection. ${ }^{5}$ The same group ${ }^{6}$ and others ${ }^{7}$ have found monoclonal antibodies to circulating $T$ cell subsets of use in differentiating between CMV infection and rejection in the kidney. In heart transplant recipients changes in circulating $T$ cell subset ratios have been found to be more specific for indicating CMV infection than rejection. ${ }^{8}$ In an earlier report one of us $^{9}$ was concerned that some of the biopsy specimens reported as moderate rejection might be viral infection with myocyte necrosis and a lymphocytic infiltration. With increasing numbers of heart transplant patients it was decided to review the Papworth experience of CMV infection and its possible effects on the heart.

In the normal management of patients after transplantation endomyocardial biopsy specimens and

Accepted for publication 21 July 1988 serum samples are taken at regular intervals. ${ }^{10}$ These routine examinations have given us the opportunity to study the histology of CMV infection in the human heart. In a substantial proportion of heart transplant patients who have not experienced CMV before the operation and who receive a heart from a donor with evidence of previous CMV infection the CMV in the donor heart may reactivate and produce a primary infection in the recipient. ${ }^{1}$

\section{Material and methods}

Forty three patients who received heart transplants and who had no detectable CMV antibody before transplantation by complement fixation test ${ }^{11}$ or competitive enzyme linked immunosorbent assay (ELISA) $^{12}$ were studied. Twenty two patients experienced primary CMV infection and showed CMV seroconversion about 57 days after transplantation and produced significant amounts (above 0.33 arbitrary units per $0.1 \mathrm{ml}$ serum) ${ }^{1}$ of CMV specific IgM (table 1) ${ }^{13}$ Half of these patients received hearts from CMV-positive donors. All the endomyocardial biopsy specimens, which had been taken up to the time of the CMV antibody titre change (when any specific inflammatory changes should have occurred), were reviewed. Twenty one control cases were selected who did not develop primary CMV infection over the same period after transplantation; only one of these control patients received a heart from a CMV-positive donor. All the patients in this study were receiving immunosuppressive treatment with cyclosporin $\mathbf{A} .^{.4}$ In all the 
Table 1 Patient details

\begin{tabular}{|c|c|c|}
\hline & Primary $C M V$ & Control group \\
\hline $\begin{array}{l}\text { Number } \\
\text { Male/female }\end{array}$ & $\begin{array}{l}22 \\
20 / 2\end{array}$ & $\begin{array}{l}21 \\
19 / 2\end{array}$ \\
\hline $\begin{array}{l}\text { Age in years } \\
\text { Range } \\
\text { Mean }\end{array}$ & $\begin{array}{l}34-52 \\
43 \cdot 5\end{array}$ & $\begin{array}{l}15-54 \\
34 \cdot 9\end{array}$ \\
\hline $\begin{array}{l}\text { Duration of study } \\
\text { Range (days) } \\
\text { Mean }\end{array}$ & $\begin{array}{l}27-119 \\
57 \cdot 3\end{array}$ & $\begin{array}{l}28-108 \\
57 \cdot 8\end{array}$ \\
\hline $\begin{array}{l}\text { Donor CMV state } \\
\text { Positive } \\
\text { Negative } \\
\text { Not known }\end{array}$ & $\begin{array}{r}11 \\
8 \\
3\end{array}$ & $\begin{array}{r}1 \\
19 \\
1\end{array}$ \\
\hline $\begin{array}{l}\text { Recipient disease } \\
\text { Ischaemic } \\
\text { Dilated cardiomyopathy } \\
\text { Hypertrophic cardiomyopathy } \\
\text { Endomyocardial fibrosis } \\
\text { Myocarditis } \\
\text { Rheumatic }\end{array}$ & $\begin{array}{l}9 \\
8 \\
1 \\
0 \\
2 \\
2\end{array}$ & $\begin{array}{l}8 \\
9 \\
1 \\
1 \\
1 \\
1\end{array}$ \\
\hline
\end{tabular}

$\mathrm{CMV}=$ cytomegalovirus infection .

biopsy specimens, the rejection reaction was graded according to Pomerance and Stovin. ${ }^{10}$ Besides rejection, note was made of any multinucleation of myocytes, or of interstitial cells, of any large nuclei with increased chromatin and blurred outline, and of any haloed "owl-eye" nuclei.

\section{Results}

The mean time from operation to the development of primary CMV infection was $57 \cdot 3$ days (range 27-119 days). Three of the controls and nine of the cases of primary infection developed Epstein-Barr virus (EBV) infection, diagnosed by an increase in EBV viral capsid antigen IgG antibody titre. In all but one case this occurred well after CMV infection; this one case was in the primary CMV infection group. One other case in the primary group developed a herpes simplex virus infection, detected by a rise in complement fixing titre, and this also occurred after the CMV infection.

There was no significant difference (Student's $t$ test) in the distribution of grades of rejection between the endomyocardial biopsy specimens in the CMV infection group and those of the control group (table 2), nor were there any differences in the primary infection group between those receiving hearts from the CMVpositive donors and those receiving hearts from CMVnegative donors.

The subsequent clinical course of the patients in the CMV infection group differed from the controls in that one of the five deaths in the primary infection group was due to disseminated CMV infection complicated by Candida pneumonia and peritonitis occurring 22 days after the serological detection of the CMV
Table 2 Biopsy sets

\begin{tabular}{lll}
\hline & \multicolumn{2}{l}{ No $(\%)$} \\
\cline { 2 - 3 } & Primary CMV & Control group \\
\hline All cases: & & \\
Rejection grade & & \\
$\quad$ No rejection & & \\
Minimal & $23(20 \cdot 0)$ & $25(20 \cdot 7)$ \\
Mild & $51(44 \cdot 4)$ & $32(26 \cdot 4)$ \\
Moderate & $35(30 \cdot 4)$ & $56(46 \cdot 3)$ \\
Severe & $6(5 \cdot 2)$ & $8(6 \cdot 6)$ \\
Nuclear changes & 0 & 0 \\
Multinuclear interstitial & & \\
Multinuclear myocyte & 4 & 3 \\
Large, blurred interstitial & 3 & 1 \\
Large, blurred myocyte & 9 & 6 \\
Primary cases and donor state: & 15 & 12 \\
& & \\
Rejection grade & Donor CMV & Donor CMV \\
No rejection & positive & negative \\
Minimal & $14(25 \cdot 0)$ & $7(16 \cdot 3)$ \\
Mild & $23(41 \cdot 1)$ & $19(44 \cdot 2)$ \\
Moderate & $17(30 \cdot 4)$ & $13(30 \cdot 2)$ \\
\hline
\end{tabular}

infection. Two of the primary CMV infection group died of coronary artery disease associated with transplant and both of these had had EBV infections. The other two deaths in the primary infection group were due to lymphoma and rejection. One of the two control patients died from bacterial infection. The remaining patient in the control group underwent retransplantation for probable recurrence of his rheumatic myocarditis.

None of the biopsy specimens showed typical "owleye" nuclei of CMV infection. There was no difference between the two groups in the incidence of multinucleate myocytes (three primary, one control), multinucleate interstitial cells (4:3), hyperchromatic blurred nuclei in myocytes (15:12), hyperchromatic blurred nuclei in interstitial cells (10:8), interstitial oedema (9:6), or vasculitis (2:2). In both groups these changes were found on average a month (nine to 119 , mean 29.6 days) after transplantation. The hyperchromatic blurred myocyte nuclear change in the primary infection cases receiving CMV-positive donor hearts occurred on average 18.4 days (9-40 days) after transplantation; this nuclear change was seen on average at 31.8 days (11-63 days) in those receiving hearts from CMV-negative donors and at $\mathbf{4 2 . 7}$ days (10-76 days) in the control group. Although this time of 18.4 days is just significantly shorter $(p<0.5)$ than the other two groups, the nuclear change is not sufficiently distinctive to enable a diagnosis of CMV infection to be made.

\section{Discussion}

The results indicate that there is no evidence of a 
cellular myocardial infiltrate or of non-specific nuclear changes associated with primary infection with $\mathrm{CMV}$, even though there is evidence ${ }^{1}$ that the donor heart is the most common source of the infecting virus. This study suggests that a non-specific nuclear change may occur earlier in the biopsy specimens, from CMVnegative patients receiving hearts than from CMVpositive donors, but this change is not associated specifically with CMV infection. In the infant case of CMV myocardial infection described by Iwasaki et al ${ }^{4}$ lymphocytic and macrophage reaction was sparse, and no mention as made of any cellular reaction being present in the two cases reported by Myerson et al..$^{3}$ In mice it has been shown that the heart can transmit CMV infection and in this model immunosuppression exacerbated the infection in both primary and latently infected animals. ${ }^{15}$ Further studies indicated that transmission of the CMV infection was unlikely to be through any of the donor leucocytes carried over in the heart. ${ }^{16}$

Earlier speculation' that moderate rejection might be confused with a cellular response to $\mathrm{CMV}$ infection was due to CMV reactivation following increased immunosuppression for moderate rejection. This earlier observation was made on patients receiving conventional immunosuppressive treatment ${ }^{17}$; all of the patients in this study were receiving cyclosporin $A$. Although CMV does not seem to produce a cellular infiltration in the myocardium that is likely to be confused with the infiltrate of rejection, CMV infected cells with characteristic "owl-eye" nuclei may be found in myocardial biopsy specimens and at necropsy before serological evidence of infection. No such infected cells were seen in any of the specimens reviewed for this study. Even though the nuclear changes observed were more common in the primary infected group than in the controls these differences were not significant. The possibility that the nuclear changes seen both in the cases of primary infection and in the controls might be due to some virus other than CMV cannot be discounted, although our evidence indicates that EBV and herpes simplex virus are unlikely candidates.

The incidence of lethal coronary artery disease in the cases of primary infection is of interest in view of the recent suggestions that $\mathrm{CMV}$ infection may be related to coronary atherosclerosis. ${ }^{18}$

In conclusion, there is no evidence to suggest that primary CMV infection is associated with a cellular myocardial infiltrate that could be mistaken for rejection in the Papworth heart transplant patients. Furthermore, there is no evidence that CMV infection is often associated with specific nuclear changes in interstitial or myocardial cells. Lastly, there is no evidence in this series to suggest that $\mathrm{CMV}$ infection acts as a clinically important immunosuppressant.

\section{References}

1 Wreghitt TG, Hakim M, Gray JJ, Kucia A, Wallwork J, English TAH. Cytomegalovirus infections in heart and heart and lung transplant recipients. J Clin Pathol 1988;41:660-7.

2 Wink K, Schmitz H. Cytomegalovirus myocarditis. Am Heart J 1980;100:667-72.

3 Myerson D, Hackman RC, Nelson JA, Ward DC, McDougall JK. Widespread presence of histologically occult cytomegalovirus. Hum Pathol 1984;15:430-9.

4 Iwasaki T, Monma N, Satodate R, et al. Myocardial lesions by Coxsackie virus B3 and cytomegalovirus infection in infants. In: Sekiguchi M, Olsen EGJ, Goodwin JF, eds. Myocarditis and related disorders. Proceedings of the International Symposium on cardiomyopathy and myocarditis. Tokyo: Springer-Verlag, 1985:167-72.

5 Richardson WP, Colvin RB, Cheeseman SH, et al. Glomerulopathy associated with cytomegalovirus viremia in renal allografts. $N$ Engl J Med 1981;305:57-63.

6 Cosimi AB, Colvin RB, Burton RG, et al. Use of monoclonal antibodies to $\mathrm{T}$-cell subsets for immunologic monitoring and treatment in recipients of renal allografts. $N$ Engl $J$ Med 1981;305:308-14.

7 Dafoe DC, Stoolman LM, Campbell DA, Lorber MI, Waskerwitz J, Turcotte JG. T cell subset patterns in cyclosporine-treated renal transplant recipients with primary cytomegalovirus disease. Transplantation 1987;43:452-4.

8 Maher P, O'Toole CM, Wreghitt TG, Spiegelhalter DJ, English TAH. Cytomegalovirus infection in cardiac transplant recipients associated with chronic $T$ cell subset ratio inversion with expansion of a Leu-7 ${ }^{+}{\mathrm{Ts}-\mathrm{c}^{+}}^{+}$subset. Clin Exp Immunol 1985;62:515-24.

9 Stovin PGI. The morphology of myocardial rejection and transplantation pathology. In: Calne RY, ed. Transplantation immunology; clinical and experimental. Oxford: Oxford University Press, 1984:78-100.

10 Pomerance A, Stovin PGI. Heart transplant pathology: the British experience. J Clin Pathol 1985;38:146-59.

11 Bradstreet CMP, Taylor CED. Technique of complement fixation test applicable to the diagnosis of virus diseases. Monthly Bulletin of the Ministry of Health and Public Health Laboratory Service 1962;21:96-104.

12 Wreghitt TG, Hicks J, Gray JJ, O'Connor C. Development of a competitive enzyme-linked immunosorbent assay for detecting cytomegalovirus antibody. J Med Virol 1986;18:119-29.

13 Wreghitt TG, Gray JJ, Chandler C. Prognostic value of cytomegalovirus IgM antibody in transplant recipients. Lancet 1986;i:1157-8.

14 Wallwork J, Cory-Pearce R, English TAH. Cyclosporine for cardiac transplantation: U.K. trial. Transplant Proc 1983;15(Suppl 1):2559-67.

15 Rubin RH, Wilson EJ, Barrett LV, Medearis DN. Primary cytomegalovirus infection following cardiac transplantation in a murine model. Transplantation 1984;37:306-10.

16 Sissons JGP, Borysiewicz LK, Rodgers B, Scott D. Cytomegalovirus-its cellular immunology and biology. Immunol Today 1986;7:57-61.

17 English TAH, McGregor C, Wallwork J, Cory-Pearce R. Aspects of immunosuppression for cardiac transplantation. Heart Transplantation 1982;1:280-4.

18 Adam E, Melnick JL, Probtsfield JL, et al. High levels of cytomegalovirus antibody in patients requiring vascular surgery for atherosclerosis. Lancet 1987;ii:291-3.

Requests for reprints to: Dr P G I Stovin, Papworth Hospital, Papworth Everard, Cambridge CB3 8RE, England. 